\title{
ТИПОВІ СЛІДЧІ СИТУАЦІЇ РОЗСЛІДУВАННЯ ВБИВСТВ, УЧИНЕНИХ ІНОЗЕМЦЯМИ НА ТЕРИТОРІЇ УКРАЇНИ, ТА НАПРЯМИ ЇХ ВИРІШЕННЯ
}

Замула Б. А.

У науковій статті досліджено сутність та юридичну природу типових слідчих ситуацій, із якими доводиться стикатись слідчим у процесі розслідування вбивств, учинених іноземцями на території України. Обгрунтовано, що обрання напряму й алгоритму розслідування вбивств, учинених іноземцями на території України, здебільшого залежить від слідчої ситуації, котра складається на мить виявлення ознак кримінального правопорушення, тому з метою оптимізації діяльності слідчих і запропоновані відповідні напрями їх вирішення.

Ключові слова: типові слідчі ситуаціі, розслідування, кримінальне провадження, вбивство, іноземець.

В научной статье исследована сущность и юридическая природа типичных следственных ситуаций, с которыми приходится сталкиваться следователям при расследовании убийств, совершенных иностранцами на территории Украины. Обосновано, что избрание направления и алгоритма расследования убийств, совершенных иностранцами на территории Украины, в основном зависит от следственной ситуации, складывающейся на момент выявления признаков уголовного преступления. Поэтому с целью оптимизации деятельности следователей и предложены соответствующие направления их решения.

Ключевые слова: типичные следственные ситуации, расследование, уголовное производство, убийство, иностранец.

Zamula B. A. Typical investigative situations of investigation of murders committed by foreigners on the territory of Ukraine and directions for their solution

The scientific article examines the essence and legal nature of typical investigative situations that investigators have to deal with when investigating murders committed by foreigners in Ukraine. It is substantiated that the choice of the direction and algorithm of investigation of murders committed by foreigners on the territory of Ukraine, mostly depends on the investigative situation that develops at the time of detection of signs of a criminal offense.

Based on the generalization of the practice of investigating murders committed by foreigners on the territory

() Замула Б. А., 2020 of Ukraine, we single out a number of types of typical investigative situations of the initial stage of investigation:

The first situation is that criminal proceedings have been instituted in connection with a report of premeditated murder, the identity of the offender was detained immediately after the crime was committed, the identity of the victim has been established, the circumstances of the incident are obvious and confirmed by evidence.

The second investigative situation is that criminal proceedings have been instituted in connection with a report of premeditated murder, the identity of the perpetrator has been established but not detained, and the identity of the victim has been established.

The third investigative situation is that criminal proceedings have been instituted in connection with the information about the discovery of a corpse with obvious signs of violent death, the identity of the criminal has not been established, but witnesses have seen him, the identity of the victim has been established.

The fourth situation - criminal proceedings have been initiated on the fact of finding the corpse of an unidentified person with obvious signs of violent death, the perpetrator has not been identified, there are no witnesses to the incident.

In order to optimize the activities of investigators appropriate areas for solving typical investigative situations are proposed.

Key words: typical investigative situations, investigation, criminal proceedings, murder, foreigner.

Постановка проблеми та іï актуальність. Діяльності слідчих підрозділів під час розслідування кримінальних правопорушень, як на початковому, так і на наступному етапах розслідування, визначається залежно від обставин, котрі підлягають установленню та доказуванню. Ця діяльність проявляється варіативним (залежно від обставин кримінального провадження) алгоритмом певних процесуальних дій, які допомагають якнайшвидше розслідувати кримінальне правопорушення. Обрання напряму й алгоритму розслідування вбивств, учинених іноземцями на території України, здебільшого залежить від слідчої ситуації, що складається на мить виявлення ознак 
кримінального правопорушення. Тобто організація та планування розслідування в конкретному провадженні значно залежить від слідчої ситуації. Слідча ситуація більшістю практиків (81\% опитаних) розглядається як наукова криміналістична категорія. Проте, на наш погляд, вона має не лише теоретичне, а й насамперед прикладне значення для методики розслідування.

Аналіз останніх досліджень і публікацій. Концептуальні основи криміналістичної слідчої ситуації детально розглянули у своїх працях такі науковці: В.П. Бахін, С.В. Веліканов, А.Ф. Волобуєв, Т.С. Волчецька, В.К. Гавло, В.Г. Гончаренко, В.А. Журавель, А.В. Іщенко, О. М. Колесніченко, В.О. Коновалова, Є.Д. Лук'янчиков, Г.А. Матусовський, О.С. Саінчин, М.В. Салтевський, М.О. Селіванов, В.В. Тіщенко, В.Ю. Шепітько.

Однак окремого дослідження щодо типових слідчих ситуацій під час розслідування вбивств, учинених іноземцями на території України, немає, що й зумовило вибір напряму наукового пошуку.

Метою статті $\epsilon$ розкриття основних типових слідчих ситуацій, які виникають під час розслідування вбивств, учинених іноземцями на території України, й запропонувати напрями їх вирішення.

Виклад основного матеріалу. На основі вивчення практики розслідування вбивств можна виокремити низку типових слідчих ситуацій, розкриття сутності яких дозволить повніше досліджувати обставини події. Однак ці слідчі ситуації на сьогодні детально досліджені вченими-криміналістами, а оскільки специфіка розслідування вбивств саме іноземцями полягає в алгоритмі дій слідчих, залежно від ситуацій щодо особи, яка причетна до вчинення певного кримінального правопорушення, тому ми спробуємо їх розглянути та проаналізувати.

Зазвичай інформація про типові слідчі ситуації $\epsilon$ результатом узагальнення практики розслідування певного виду злочинів. Так уважає й С.С. Чернявський, який убачає в типовій слідчій ситуації інформаційну модель із найбільш значущими властивостями й ознаками процесу розслідування у кримінальних провадженнях щодо злочинів певної категорії [1, с. 405].

Так, нами було вивчено практику розслідування вбивств, учинених іноземцями на території України і внслідок цього виокремити низку видів типових слідчих ситуацій.

Перша ситуація - кримінальне провадження розпочато у зв'язку з повідомленням про умисне вбивство, особу злочинця затримано безпосередньо після вчинення злочину, особу nomep- пілого встановлено, обставини події очевидні та підтверджуються зібраними доказами.

Звичайно, зазначена ситуація $є$ найбільш сприятливою для розслідування. Розслідування у такій ситуації скероване від особи до доведення вини у вчиненні кримінального правопорушення.

Основним алгоритмом дій слідчого для вирішення тактичних завдань у цій ситуації $є$ : ОМП, у процесі якого здійснити: аналіз слідової картини злочину (часу, місця, знаряддя вчинення та інших обставин), способу вчинення вбивства, встановлення форми вини, мотиву й мети вчинення кримінального правопорушення; огляд трупа, огляд предметів і слідів, виявлених на місці події; огляд взуття й одягу затриманої особи; освідування затриманого; отримання зразків для порівняльного дослідження (крові, волосся, слини); призначення судово-медичної експертизи трупа, цитологічної, імунологічної, медико-криміналістичної, дактилоскопічної та інших видів дослідження; допит свідків; збір усіх необхідних доказів для повідомлення особі про підозру в учиненні умисного вбивства або заходів, необхідних для затримання особи.

Узагалі, залежно від правового статусу підозрюваного іноземного громадянина на території України, можна виділити такі типові слідчі ситуації:

1. Іноземець на території України знаходиться нелегально й не володіє імунітетом від кримінальної юрисдикції України;

2. Іноземець на території України знаходиться легально й не володіє імунітетом від кримінальної юрисдикції України. В цьому разі за часом перебування в Україні можна виділити ситуації, коли іноземець:

1) постійно проживає в Україні й має посвідку на проживання;

2) тривалий час знаходиться у країні (студент або аспірант, керівник іноземної фірми або спільного підприємства, журналіст тощо);

3) короткочасно перебуває в Україні (турист, спортсмен, артист, проїжджає через територію України транзитом).

3. Іноземець має або користується дипломатичним імунітетом в Україні (співробітники консульств, дипломатичних представництв, представництв міжнародних організацій із «функціональним» імунітетом).

Друга слідча ситуація - кримінальне провадження розпочато у зв'язку з повідомленням про умисне вбивство, особу злочинця встановлено, але не затримано, особу потерпілого встановлено. 
Такій слідчій ситуації притаманне переховування злочинця, коли в нього виникає страх перед відповідальністю, або він, усвідомлюючи свою вину та перебуваючи в шоковому стані, намагається втекти задля уникнення покарання або знищення слідів.

У такій ситуації процесуальні дії слідчого передусім будуть спрямовані на встановлення місцезнаходження особи, яка вчинила певний злочин. Важливе значення в цьому разі відіграє взаємодія слідчого з оперативними підрозділами, працівниками Державної прикордонної служби, Державної міграційної служби України та іншими органами та підрозділами.

Найперше слідчому потрібно оглянути місце події, вилучивши всі матеріальні сліди. Дослідження (зокрема із залученням фахівців) слідів, залишених злочинцем на місці події, дозволяє в деяких випадках отримати приблизний опис зовнішності, анатомічних і функціональних ознак особи, що вчинила злочин, які можуть допомогти під час розшуку «за гарячими слідами». Важливо вживати всіх заходів, спрямованих на встановлення свідків-очевидців злочину, осіб, котрі володіють будь-якою інформацією про те, що сталось і його учасників.

У цьому разі слідчі повинні вжити заходів для введення відповідних оперативних планів. Так, за рішенням начальника органу (підрозділу) поліції можна ввести в дію спеціальні оперативні плани «Грім», «Перехват» або «Сирена». Надалі потрібно діяти згідно із цими планами і вказівками керівника поліцейської операції.

Крім цього, доцільно використовувати:

1) централізовані криміналістичні та розшукові обліки;

2) спеціалізовані обліки:

- система «Аркан» - призначена для своєчасного, достовірного та функціонально повного інформаційно-аналітичного забезпечення діяльності суб'єктів системи щодо здійснення ними заходів із запобігання й недопущення в'їзду в Україну або виїзду з України осіб, яким, згідно із законодавством, не дозволений в'їзд в Україну або яких тимчасово обмежено у праві виїзду з України, зокрема і згідно з дорученнями правоохоронних органів, розшуку в пунктах пропуску через державний кордон осіб, що переховуються від органів слідства та суду, ухиляються від відбуття кримінальних покарань, припинення протиправної діяльності фізичних і юридичних осіб, котрі незаконно переправляють мігрантів в Україну або транзитом переміщують їх через терито- рію України, посилення контролю за дотриманням правил в'їзду, виїзду, перебування в Україні іноземців та осіб без громадянства, а також виконання інших завдань у правоохоронній сфері, відповідно до законодавства.

- ІП «Мігрант» - до цієї бази внесенню підлягають відомості щодо: іноземців та осіб без громадянства, які порушили встановлені законодавством правила в'їзду, виїзду, перебування в Україні і транзитного проїзду через їі територію; громадяни України, котрі порушили встановлені законодавством правила в'їзду іноземців та осіб без громадянства в Україну, їх виїзду з України i транзитного проїзду через іï територію. Внесення відомостей до ІП «Мігрант» визначається порядком інформаційної взаємодії між МВС та відповідним ЦОВВ [2, с. 78].

Надалі в разі затримання підозрюваного: пред'явити підозру; допитати; провести його освідування; вилучити його одяг, взуття та біологічні зразки для проведення відповідних експертиз; призначити експертизи із залученням спеціалістів (судово-медичної - трупа; судово-психологічної, судово-психіатричної - підозрюваного та інших криміналістичних експертиз); допити свідків; за потреби - обшуки за місцем проживання підозрюваного; за умов невстановлення місцезнаходження злочинця - винесення клопотання про оголошення особи в розшук.

Третя слідча ситуація - кримінальне провадження розпочато у зв'язку з отриманням інформації про виявлення трупа з явними ознаками насильницької смерті, особу злочинця не встановлено, але свідки бачили його, особу потерпілого (жертви злочину) встановлено.

Така ситуація $\epsilon$ проблемною на початковому етапі розслідування, адже відсутні будь-які відомості про особу злочинця. Позитивним $є$ лише той факт, що особу потерпілого встановлено завдяки документам, які були в потерпілого або від свідків, котрі виявили злочин і володіють інформацією про потерпілого, а, відповідно, слідчий може використати ці ідеальні сліди для встановлення особи і причетності їі до вчиненого злочину.

3 огляду на специфіку цього злочину доцільним $\epsilon$ встановлення наявності на місці події чи поблизу нього відеокамер (у разі позитивного результату необхідно отримати тимчасовий доступ до речей). Відеоматеріали підлягають огляду, а за потреби вилученню та визнанню речовим доказом у кримінальному провадженні. На таких відеозаписах може бути зафіксовано особу, яка вчинила кримінальне правопорушення, та механізм злочину або 
принаймні встановлено осіб із підозрілою поведінкою (тікали з місця події, поводились схвильовано тощо).

Особливого значення сьогодні набуває встановлення оглядових камер із новим аналітичним модулем розпізнавання обличчя. Ця технологія використовується у великих корпораціях із певною обмеженістю доступу, а також, наприклад, у системі безпеки аеропорту, в якій уже розпізнавання здійснюється у процесі обробки масиву зображень облич, отриманого з відеопотоку. Навіть такі пристрої, як ноутбук чи смартфон, що наявні в повсякденному житті, дозволять скористатись можливістю цієї технології. Розпізнавання обличчя $є$ актуальним та використовується в багатьох сферах життя. Системи не потребують вартісного обладнання, для певної якості роботи достатньо застосувати веб-камеру. Звичайно самої веб-камери недостатньо, потрібна програма, яка оброблятиме отримані зображення та «вирішуватиме» згідно із заданим алгоритмом та методу роботи, чи потрібно надати доступ [3].

Тому сьогодні у великих метрополісах установлюються відеокамери з інтелектуальною системою розпізнавання обличчя на основі методу Віоли-Джонса. Так, у Києві встановлено новий аналітичний модуль відеоспостереження в межах проєкту «Безпечне місто» (Kyiv Smart Safe City), Цей модуль дозволить розшукувати осіб, які вчинили правопорушення, не лише за допомогою спеціалізованих камер розпізнавання обличчя. Він фіксує зображення з будь-якої камери, що встановлена в межах локальної мережі, та порівнює їх із базою правопорушників, котра була створена правоохоронними органами. Крім того, офлайн-режим дозволяє шукати людей у базі за фотографією обличчя. За допомогою отриманого з камер фоторобота правопорушника система аналізує базу даних та знаходить потрібну людину.

Тому як одним із напрямів подальшого розвитку боротьби зі злочинністю було б доцільно цю програму розвивати на території всієї України та надавати статус користувача працівникам правоохоронних органів із метою встановлення та розшуку осіб, які причетні до вчинення кримінальних правопорушень.

За наявності свідків можливо скласти фоторобот підозрюваної особи. На сьогодні в інших країнах значного поширення набуває програмне забезпечення для 3D моделювання обличчя (KLIM 3D). Ця програма пропонує інноваційну технологію складання суб'єктивних портретів, що дозволяє підвищити ефективність роботи спеціалістів.
KLIM 3D має багатий антропометричний довідковий каталог, який полегшує роботу експертів із фотороботами. Це означає, що стереотипні риси обличчя різних географічних та етнічних груп, такі як колір шкіри, форма носа, можуть бути застосовані до 3D-моделей KLIM одним клацанням миші. Виконуючи ці додатки одним клацанням миші, фахівці можуть уносити зміни та змінювати вимірювання зазначених особливостей на моделі. Це дозволяє будувати моделі досить реалістичними , а слідчим - установлювати підозрюваного якнайшвидше. Моделі, побудовані за допомогою KLIM 3D, можна спрямовувати у програмне забезпечення для розпізнавання обличчя та порівняти ïx із реальними особами із бази даних.

Для забезпечення того, щоб 3D-моделі ідеально відповідали реальній особі, KLIM 3D дозволяє експертам додати текстуру та колір шкіри та особливості, такі як тіло, родимки та шрами.

За допомогою KLIM 2D, яка входить у програмний комплекс KLIM 3D, до моделей можна додавати аксесуари для голови, волосся та обличчя, такі як шапки, пірсинг та окуляри. Крім цього, можна додавати вираз обличчя, що позначають такі емоції, як гнів і страх. Завдяки цій функції можливо прив'язати особу до місця вчинення злочину [4].

Однозначно, що використання такого програмного забезпечення значно пришвидшить установлення особи й допоможе слідчим у швидкому розслідуванні. Таку позицію підтримує й К.І. Єщенко, який писав, що застосування методу моделювання також можливе у процесі проведення такої слідчої (розшукової) дії, як огляд трупа. Надалі за допомогою створеної комп'ютерної моделі, на якій будуть відображені сліди видимих тілесних ушкоджень, негативні ознаки (відсутність крапель крові під раною), слідчий може представити цю модель для більш докладного опису лікарем. Надалі з використанням такої тривимірної моделі, якщо немає необхідності проведення аналізу тканин, можна виключити, наприклад, ексгумацію [5, с. 95].

Таким чином, використання різноманіття комп'ютерних програм тривимірного моделювання може надати істотну допомогу слідчим для встановлення особи, яка вчинила вбивство.

Установивши й затримавши особу, котра вчинила вбивство, слідчий може пред'явити його для впізнання свідкам.

Четверта ситуація - кримінальне провадження розпочато за фактом виявлення трупа невстановленої особи з явними ознаками насиль- 
ницької смерті, злочинця не встановлено, свідки події відсутні.

Основними завданнями на початковому етапі розслідування в такій ситуації $€$ встановлення особи жертви та збір доказів причетності особи до вчинення вбивства. Зазначені завдання $є$ проміжними тактичними завданнями розслідування, а основне - це встановлення особи, що вчинила вбивство в умовах неочевидності.

Варто зазначити, що досудове розслідування в цій ситуації здійснюють за типовим алгоритмом розслідування неочевидних убивств. Першочерговою й невідкладною слідчою (розшуковою) дією буде проведення огляду місця події та трупа. У процесі огляду можуть бути виявлені ознаки боротьби, які надалі дозволяють визначити обставини вчинення вбивства, і сліди певної особи. Паралельно - проводять заходи, спрямовані на виявлення свідків убивства, а також інших носіїв інформації (камер відеоспостереження). Обов'язково призначається судово-медична експертиза трупа й речових доказів, а також, залежно від виявлених на місці події об'єктів, низка інших експертиз (дактилоскопічна, трасологічна, балістична, імунологічна, цитологічна, медико-криміналістична та інші).

Для встановлення місцезнаходження підозрюваного в учиненні цього злочину ефективним здебільшого $\epsilon$ проведення негласних слідчих (розшукових) дій (далі - НС(Р)Д) (89\% опитаних). Відповідно до процесуальної класифікації, законодавець виділяє дві групи НС(Р)Д. До першої групи належить НС(Р)Д, що розміщені в §2 цієї глави, який має назву «втручання у приватне спілкування»:

- аудіо-, відеоконтроль особи;

- арешт, огляд і виїмка кореспонденції;

- зняття інформації із транспортних телекомунікаційних мереж;

- зняття інформації з електронних інформаційних систем (ч. 4 ст. 258 КПК).

Необхідно звернути увагу, що «арешт, огляд і виїмку кореспонденції» науковці розглядають як три окремі самостійні дії: накладення арешту на кореспонденцію; огляд кореспонденції; виїмка кореспонденції [6, с. 575-577].

Унаслідок вивчення матеріалів кримінальних проваджень та анкетувань оперативних та слідчих працівників найбільш розповсюдженими НС(Р)Д, які проводились за умов убивства, вчиненого іноземцем на території України, були такі: аудіо-, відеоконтроль особи (ст. 260 КПК України) - 31\%; зняття інформації із транспортних телекомунікаційних мереж (263 КПК України) - 24\%; установлення місцезнаходження радіоелектронного засобу (ст. 268 КПК України) - 23\%; аудіо-, відеоконтроль місця (ст. 270 КПК України) - 12\%; зняття інформації з електронних інформаційних систем без відома iі власника, тимчасового власника або утримувача (ст. 264 КПК України) - 7\%; інші - 3\%.

Висновки. Отже, обрання напряму й алгоритму розслідування вбивств, учинених іноземцями на території України, здебільшого залежить від слідчої ситуації, котра складається на мить виявлення ознак кримінального правопорушення. Тому алгоритм слідчого, на нашу думку, щодо розслідування вбивств, учинених іноземцями на території України, має бути таким: оцінка первинної інформації; аналіз слідчої ситуації; висунення версій щодо обставин учинення кримінального правопорушення; виокремлення тактичних завдань і планування розслідування (враховуючи статус особи злочинця); особливості проведення окремих слідчих (розшукових) дій і тактичних операцій.

\section{Література}

1. Чернявський С.С. Теоретичні та практичні основи методики розслідування фінансового шахрайства : дис. ... д-ра юрид. наук : 12.00.09. Київ, 2010. 610 с.

2. Дабіжа Д.В. Використання обліків та автоматизованих інформаційних систем під час розслідування кримінальних правопорушень : дис. канд. юр. наук : 12.00.09. Київ, 2017. 288 с.

3. Голубяк І.М. Методи розпізнавання облич: короткий огляд. URL: http://itcm.comp-sc. if.ua/2017/Holubiak.pdf (дата звернення 15.07.2020).

4. KLIM 3D. 3D Figure Modelling Software. URL: https://papilon.com.tr/en/klim-3d-2/м (дата звернення 15.07.2020).

5. Єщенко К.І. Застосування методу моделюванняпід часпроведення слідчих (розшукових) дій. Проблемні аспекти експертної практики: збірник матеріалів круглого столу / редкол.: Кобилянський О.Л., Антонюк П.Є., Свобода Є.Ю.; Київ : ННІПФЕКП НАВС. 2014. С. 93-97.

6. Кримінальний процесуальний кодекс України. Науково-практичний коментар / за заг. ред. проф. В.Г. Гончаренка, В.Т. Нора, М.Є. Шумила. Київ : Юстініан, 2012. 1224 с.

Замула Б. А., ад'юнкт кафедри криміналістики та судової медицини Національної академії внутрішніх справ 